\title{
The Art of Appeal in Electronic Commerce
} Understanding the Impact of Product and Website Quality on Online Purchases Liu, Albert Fei; Xiao, Bo Sophia; Lim, Eric T. K.; Tan, Chee Wee

Document Version

Accepted author manuscript

Published in:

Internet Research

DOI:

10.1108/IntR-09-2016-0280

Publication date:

2017

License

Unspecified

Citation for published version (APA):

Liu, A. F., Xiao, B. S., Lim, E. T. K., \& Tan, C. W. (2017). The Art of Appeal in Electronic Commerce:

Understanding the Impact of Product and Website Quality on Online Purchases. Internet Research, 27(4), 752 771. https://doi.org/10.1108/IntR-09-2016-0280

Link to publication in CBS Research Portal

\section{General rights}

Copyright and moral rights for the publications made accessible in the public portal are retained by the authors and/or other copyright owners and it is a condition of accessing publications that users recognise and abide by the legal requirements associated with these rights.

Take down policy

If you believe that this document breaches copyright please contact us (research.lib@cbs.dk) providing details, and we will remove access to the work immediately and investigate your claim. 


\title{
The Art of Appeal in Electronic Commerce: Understanding the Impact of Product and Website Quality on Online Purchases
}

\section{Albert Fei Liu, Bo Sophia Kiao, Eric T. K. Lim, Chee Wee Tan}

\author{
Journal article (Accepted manuscript)
}

CITE: The Art of Appeal in Electronic Commerce : Understanding the Impact of Product and Website Quality on Online Purchases. / Liu, Albert Fei; Xiao, Bo Sophia; Lim, Eric T. K.; Tan, Chee Wee. In: Internet Research, Vol. 27, №. 4, 2017, р. 752-771.

This article is [0 Emerald Group Publishing and permission has been granted for this version to appear here: https://research.cbs.dk/en/publications/the-art-of-appeal-in-electronic-commerce-understanding-theimpact. Emerald does not grant permission for this article to be further copied/distributed or hosted elsewhere without the express permission from Emerald Group Publishing Limited.

DOI: 10.1108/IntR-09-2016-0280

Uploaded to Research@CBS: December 2018 


\title{
The Art of Appeal in Electronic Commerce: Understanding the Impact of Product and Website Quality on Online Purchases
}

\author{
Fei Liu \\ Department of Digitalization, Copenhagen Business School \\ Copenhagen, Denmark
}

\section{Bo Xiao}

Information Technology Management Department, Shidler College of Business, University of Hawai'i at Mānoa, Honolulu, Hawaii, USA

\section{Eric T.K. Lim}

School of Information Systems and Technology Management

University of New South Wales, Sydney, Australia

\section{Chee-Wee Tan}

Department of Digitalization, Copenhagen Business School

Copenhagen, Denmark

Accepted at Internet Research (IntR).

Please do not quote or cite without permission. Comments are welcome.

Please address all correspondence to the first author. 


\title{
The Art of Appeal in Electronic Commerce: Understanding the Impact of Product and Website Quality on Online Purchases
}

\begin{abstract}
Purpose - This study advances product appeal and website appeal as focal psychological mechanisms that can be invoked by business-to-consumer (B2C) e-commerce sites to mitigate problems of information asymmetry via signaling to bolster consumers' purchase intention under the influence of trust.
\end{abstract}

Design/methodology/approach - Survey approach was employed to validate our research model.

Findings - Website appeal partially mediates the positive effect of product appeal on consumers' purchase intention. Trust in e-commerce sites not only increases purchase intention directly, but it also reinforces the positive relationship between website appeal and purchase intention while attenuating the positive relationship between product appeal and purchase intention. Service content quality, search delivery quality, and enjoyment are confirmed as positive antecedents of website appeal whereas diagnosticity and justifiability are established as positive antecedents of product appeal.

Research implications - This study not only delineates product and website appeal as complementary drivers of consumer purchase on e-commerce sites, but it also derives five signals that aid in bolstering both product and website appeal. Trust is revealed to exert a moderating influence on the impact of product and website appeal on purchase intention.

Practical implications - Practitioners should prioritize their resource allocation to enhance qualities most pertinent to product and website appeal. E-commerce sites should offer productoriented functionalities to facilitate product diagnosticity and reassure consumers of their purchase decisions.

Originality/value - This study distinguishes between product and website appeal as well as between their respective antecedents. It also uncovers how trust can alter the effects of both website and product appeal on consumers' purchase intention.

Keywords: Signaling theory, E-commerce, information asymmetry, product appeal, website appeal 


\section{INTRODUCTION}

Contemporary business to consumer (B2C) e-commerce sites strive to match their brickand-mortar counterparts in terms of conversion rates (Becerra and Korgaonkar, 2011). Due the anonymity of online transactions coupled with the spatial and temporal displacement intrinsic to e-commerce sites (Xiao and Benbasat, 2011), it is not uncommon for consumers to be concerned about the risks involved in transacting with unknown e-retailers (Gefen, 2002a; Gefen et al., 2003a; Kim et al., 2008) and the uncertainty associated with product quality (Jiang and Benbasat 2004). Consequently, e-commerce sites must not only replicate the shopping experience of brick-and-mortar stores (e.g., Wells et al., 2011), they must also present their product offerings in an appealing fashion (e.g., Jiang and Benbasat, 2007a). These efforts have culminated in the rapid growth in e-commerce sales, which more than doubled the rate of growth of their brick-and-mortar counterparts (Tamimi and Sebastianelli, 2015). However, the continued growth of e-commerce is impeded by the information asymmetry inherent in the transactional relationship between consumers and e-retailers. Consumers generally do not possess perfect information prior to purchase (Biswas and Biswas, 2004) and thus can only indirectly assess the quality of products offered on e-commerce sites via the latter's web interface (Jiang and Benbasat, 2004). Even for experienced consumers, uncertainty regarding product quality remains a valid concern (Williams, 2013). Information asymmetry hence deters consumers from committing to online purchase, which in turn limits e-commerce's market penetration. In the fourth quarter of 2016, e-commerce retail sales only accounted for $8.3 \%$ of total sales ${ }^{1}$. In this study, we seek to unleash the potential of e-commerce by confronting the problem of information asymmetry in online transactions.

Signaling theory has been espoused by researchers as a fitting theoretical lens for comprehending how information asymmetry can be alleviated (Connelly et al., 2010; Spence,

\footnotetext{
${ }^{1}$ Sales statistics are retrieved from: https://fred.stlouisfed.org/series/ECOMPCTSA.
} 
2014). Signaling theory holds that insiders (signalers) can deliberately communicate to outsiders (receivers) unobservable attributes of an artifact, a process termed as signaling (Connelly et al., 2010; Spence, 2014). Guided by signaling theory, scholars have investigated how information cues (i.e., signals related to the true quality of product offerings) conveyed by an e-commerce site alleviate information asymmetry between consumers and e-retailers by facilitating the former's evaluation of unobservable product attributes (Spence, 2014). Prior research has identified several aspects of e-commerce sites (e.g., reliable payment and userfriendly interface) that can be signaled to induce consumers' purchase behavior (Van Der Heijden et al., 2003). Likewise, past studies have uncovered product-related properties, such as diagnosticity, that can be signaled by e-commerce sites to promote sales (Jiang and Benbasat, 2004). Yet, research to-date does not distinguish between product and service related qualities that can be conveyed to consumers in e-commerce context. Insomuch as the quality of ecommerce sites consists of product quality (Wells et al., 2011) and website (service) quality (Al-Debei et al., 2015), we extend prior research by postulating the existence of distinct signaling processes for product and website (service) qualities.

Besides accentuating the underexplored parallel signaling processes, this study examines how these two signaling processes can be leveraged by e-commerce sites to entice consumers to make purchase decisions. To this end, this study draws inspiration from advertising literature that has attested to appeal as a key indicator of the effectiveness of transmitted information cues or signals in conveying the latent qualities of a given product (Johar and Sirgy, 1991). Indeed, appeal resonates with signaling theory as it captures the positive psychological effect evoked by signaling product attributes to consumers. We also draw from past studies of ecommerce examining the visual appeal of websites, which shed light on how visual appeal enhances the aesthetics and relational rewards of e-commerce sites (Campbell et al., 2013; Wells et al., 2011). In this study, we advance extant literature on e-commerce by adopting a 
broader concept of appeal to denote the ability of an e-retailer to invoke positive feelings and stimulate the cognition or emotions of consumers (Yeshin, 1998). As e-commerce sites can bolster their appeal by conveying positive attributes of their product offerings and website functionalities, we further delineate the concept of appeal into product appeal and website appeal in order to investigate how these two distinct signaling processes, both independently and in tandem, shape consumers' purchase intentions.

Prior research has testified to the pivotal role of trust in alleviating consumers' concerns when engaging in online purchases (Al-Debei et al., 2015; Becerra and Korgaonkar, 2011; Gefen, 2002a; Kim et al., 2008). A variety of measures have been introduced to foster and sustain consumers' trust, which include building brand equity (Biswas and Biswas, 2004; Kim et al., 2008, 2004), ensuring information quality (Kim et al., 2008; Rahimnia and Hassanzadeh, 2013), investing in advertisements (Aiken and Boush, 2006; Biswas and Biswas, 2004), offering warranties (Aiken and Boush, 2006), safeguarding privacy (Kim et al., 2008), securing third-party endorsements (Aiken and Boush, 2006; Biswas and Biswas, 2004; Kim et al., 2008; Özpolat and Jank, 2015), and utilizing electronic Word-of-Mouth (Al-Debei et al., 2015). In accordance with warranting theory, consumers' trust in e-commerce sites dictates their perceptions of the reliability of quality-related signals emitted by these sites (Chua and Banerjee, 2015; Walther and Parks, 2002). Conceivably, consumers' purchase intentions are driven by the extent to which their positive feelings about e-commerce sites are induced by trustworthy signals that are costly to manipulate (Walther and Parks, 2002). An in-depth appreciation of how trust influences the impact of product and website appeal on consumers' purchase decision is hence long overdue and constitutes a noteworthy venture.

We endeavor to address the following research questions in this study:

- What qualities can be signaled by an e-commerce site to enhance its product and website appeal?

- How do product and website appeal affect consumers' purchase intentions? 
- How does trust influence the impact of product and website appeal on consumers' purchase intentions?

To provide answers to the abovementioned research questions, we build on signaling theory to construct a research model (Connelly et al., 2010; Spence, 2014) that posits how product and website appeal can be induced by signaling product- (i.e., diagnosticity and justifiability) and website-related qualities (i.e., service content quality, service delivery quality, and enjoyment) respectively. Furthermore, drawing on warranting theory (Walther and Parks, 2002), we postulate that the positive effects of product and website appeal on purchase intentions are subjected to the influence of consumers' trust in e-commerce sites as signalers.

The remainder of this paper is organized as follows. In the next section, we not only introduce signaling theory along with warranting theory, both of which form the theoretical foundation for this study, but we also review extant literature on appeal. We then construct our research model together with testable hypotheses. Next, we outline our methodology for data collection and analysis. We then present the results of our data analysis before concluding with a summary of core findings and their implications for theory and practice.

\section{THEORETICAL BACKGROUND AND LITERATURE REVIEW}

\subsection{Signaling Theory}

Undesirable outcomes may emerge when transacting parties involved in a market exchange make decisions on the basis of imperfect information (Pavlou et al., 2007). This problem of information asymmetry is more pronounced in e-commerce because consumers, being estranged from e-retailers, have limited means of assessing the quality of products prior to purchase (Biswas and Biswas, 2004; Spence, 1973). High levels of information asymmetry in e-commerce settings may amplify consumers' risk perceptions (Biswas and Biswas, 2004) and correspondingly, diminish their intentions to purchase from e-commerce sites.

Signaling theory was proposed by Spence (1973) as a conceptual lens for tackling information asymmetry between two transacting parties (e.g., buyers and sellers) in a market 
interaction (Spence, 2014). To reduce buyer uncertainty, signaling theory posits that sellers may send pre-purchase signals about product quality (Kirmani and Rao, 2000). A signal is a discernible cue that is intended to convey information about unobservable attributes of an entity (Kirmani and Rao, 2000; Rao et al., 1999). Entrepreneurship studies, for example, have considered how private equity (Janney and Folta, 2006), and earnings (Michael, 2009) drive the decisions of potential investors. Likewise, prior research in e-commerce has investigated how brand equity (Chu et al., 2005), diagnosticity (Pavlou et al., 2007), service quality (Gefen, 2002b), social presence (Pavlou et al., 2007), third-party assurances (Song and Zahedi, 2007), and website quality (Wells et al., 2011) dictate online consumption behaviors.

Two research streams have scrutinized the effects of signaling in e-commerce (cf. Connelly et al., 2010; Kirmani and Rao, 2000; Wells et al., 2011). One stream of research has investigated how signals of credibility_including advertising investments (Aiken and Boush, 2006; Biswas and Biswas, 2004), reputation (Biswas and Biswas, 2004; Kim et al., 2004), and third-party endorsements (Aiken and Boush, 2006; Biswas and Biswas, 2004)-lower consumers' risk perceptions and increase their trust in e-commerce sites. This line of research applied signaling theory to explain how moral hazard, which arises from consumers' lack of trust in e-commerce sites due to information asymmetry, can be circumvented by conveying signals about the latter's trustworthiness. In comparison, the other stream of research has emphasized how branding (Chu et al., 2005), diagnosticity (Pavlou et al., 2007), social presence (Pavlou et al., 2007), and website quality (Wells et al., 2011) positively influence consumers' purchase intention. Studies belonging to this research stream have shown that firms can resolve scenarios of adverse selection (i.e., situations in which consumers have to make decisions without adequate assessment of product quality due to information asymmetry) by conveying quality-related signals to inform consumers (Kirmani and Rao, 2000). 
A signaling process typically comprise three focal elements, namely signaler, signal, and receiver (Connelly et al., 2010). Extrapolated to our study, signalers are e-commerce sites that possess information about their product offerings (e.g., Kirmani and Rao 2000), which may be inaccessible to consumers (Connelly et al., 2010). Signals are information cues conveyed by the e-commerce sites (Connelly et al., 2010; Wells et al., 2011) whereas receivers are consumers who rely on these signals to assess product and website quality (Connelly et al., 2011; Rao et al., 1999). Because the ultimate goal of signaling for e-commerce sites is to convey affirmative information cues about the quality of their product offerings and the hosting sites (Kirmani and Rao, 2000; Wells et al., 2011), this study hence differentiates between product and website appeal to capture consumers' interpretations of positive signals about product and website quality respectively.

\subsection{Appeal}

Two research streams have investigated the effects of appeal in e-commerce. The first research stream focuses on how the design of e-commerce sites fosters visual appeal, which in turn reinforces consumers' positive beliefs about and attitudes toward the sites. Specifically, Cyr et al. (2009) found that human images on an e-commerce site generated image appeal that positively influenced consumers' trust in the website. Campbell et al. (2013) and Wells et al. (2011) bore witness to visual appeal as a crucial determinant of the aesthetics and relational rewards associated with e-commerce sites. In the same vein, we contextualize the notion of appeal from advertising literature to e-commerce sites and define website appeal as the ability of an e-commerce site to evoke positive feelings and stimulate the cognition or emotions of individuals with respect to its service quality (Yeshin, 1998).

In contrast, the second research stream explores how e-commerce sites can enrich product appeal. In an experiment involving a sports watch shopping website, Jiang and Benbasat (2004) documented the positive effects of functional and visual control on consumers' perceptions of 
diagnosticity and flow. Similarly, Jiang and Benbasat (2007a) reported how the functional mechanisms of online product presentation (i.e., vividness and interactivity) improved the allure of listed products. Since the main purpose of an e-commerce site is to promote its products and encourage purchases (Jarvenpaa et al., 2000), product appeal, defined herein as the ability of an e-commerce site to evoke positive feelings and stimulate the cognition or emotions of individuals with respect to the products listed on the site (Yeshin, 1998), is instrumental in inducing consumers' purchase intention. Despite the importance of product and website appeal in e-commerce, there is a paucity of studies that have examined these concepts in-depth, much less investigate the impact of product and website appeal in tandem within the online transactional environment.

\subsection{Warranting Theory}

Walther and Parks (2002) introduced warranting theory to describe how individuals distinguish among multiple signals on the basis of their confidence in the reliability and trustworthiness of these signals. Transplanting warranting theory onto online information seeking, Chua and Banerjee (2015) asserted that individuals are inclined to trust information cues that are more costly to fabricate. In e-commerce, scholars have demonstrated that credible cues (e.g., product images) are more effective in persuading consumers to engage in purchase behaviors (Van Der Heide et al., 2013). In this study, we draw on warranting theory (Walther and Parks, 2002) to explore the role of trust in influencing the impact of product and website appeal on consumers' purchase intentions.

\section{RESEARCH MODEL AND HYPOTHESIS DEVELOPMENT}

\subsection{Relationship between Product and Website Appeal}

Product acquisition is the dominant value afforded by e-commerce sites (Lee et al., 2003). If consumers deem the products listed on an e-commerce site to be appealing, they are more likely to develop positive feelings towards the site (Gefen and Straub, 2000). Prior research has 
revealed that the provision of interactive product-oriented functionalities on an e-commerce site heightened consumers' involvement (Jiang et al., 2010), so much so that the site was regarded by consumers to be much more useful (Jiang and Benbasat, 2007b). Conceivably, consumers tend to attribute their positive feeling about the products to the merits of the hosting e-commerce site, leading to a spillover effect from product appeal onto website appeal:

Hypothesis 1: Product appeal of an e-commerce site positively influences its website appeal.

\subsection{Consequences of Product and Website Appeal}

Purchase intention reflects consumers' intention to make purchases on an e-commerce site. Past studies have confirmed that a high-quality e-commerce site is more likely to prompt consumers to make purchases on the site (Gefen et al., 2003b; Van Der Heijden et al., 2003; Wells et al., 2011, Javornik, 2016). We hence anticipate that website appeal will alleviate consumers' concerns about transacting with an e-commerce site, thereby increasing their intention to purchase from the site:

Hypothesis 2: Website appeal of an e-commerce site positively influences consumers' purchase intention.

Product appeal encompasses consumers' positive attitude towards a given product, and drives their intention to purchase the product (Ajzen and Fishbein, 1980). Jiang and Benbasat (2007a) demonstrated that positive attitudes toward the product, induced via interactive and vivid product presentation, increase consumers' purchase intention on an e-commerce site. Wells et al. (2011) also maintained that online consumers tend to purchase products that they deem to be enticing. We thus expect that product appeal will mitigate consumers' concern about receiving undesirable products from an e-commerce site, which in turn increases the former's intention to purchase from the site:

Hypothesis 3: Product appeal of an e-commerce site positively influences consumers' purchase intention. 


\subsection{Antecedents of Website Appeal}

According to Grönroos (1984), service quality is not only indicative of the performance (or outcome) of a service, but it is also reflective of the means by which this outcome is delivered to consumers. Taking into account both utilitarian and hedonic aspects of service quality, Sánchez-Hernández et al. (2009) put forward a taxonomy of hotel service quality that consists of three distinctive components: service content quality, service delivery quality, and relational/emotional service quality. This study thus adopts service content quality and service delivery quality to encapsulate the utilitarian aspect of e-commerce service quality, and enjoyment (i.e., proxy for emotional service quality) to reflect the hedonic aspect of ecommerce service quality.

\subsubsection{Service content quality}

Past studies have conceptualized service content quality as the extent to which a consumer is convinced that an e-commerce site will facilitate the accomplishment of his/her online shopping task (Hampton-Sosa and Koufaris, 2005). Accordingly, we define service content quality as consumers' perception regarding the effectiveness of service content provided by an e-commerce site in facilitating their online shopping activities (Tan et al., 2013; Van der Merwe and Bekker, 2003). In this sense, service content quality can be signaled via website functionalities implemented to facilitate product searches, streamline online purchases, and promote interactions among consumers as well as between consumers and e-retailers. Hampton-Sosa and Koufaris (2005) have alluded to the positive relationship between service content quality and website appeal for e-commerce sites. Accordingly, we hypothesize that:

Hypothesis 4: Service content quality of an e-commerce site positively influences its website appeal.

\subsubsection{Service delivery quality}

To alleviate information asymmetry in the e-commerce context, an e-commerce site can convey service delivery quality via signaling. Consumers are interested in not only the service 
content of e-commerce sites, but also how such content is delivered (Grönroos et al., 2000). Indeed, superior service content is worthless if it cannot be efficiently accessed by consumers (van Riel et al., 2001). In this study, we define service delivery quality as consumers' perception regarding the efficiency of delivering service content by an e-commerce site (Tan et al., 2013). Service delivery quality has been established in prior research as a focal dimension of e-service quality (Zeithaml et al., 2000), and empirically validated as a vital determinant of consumers' positive receptivity towards e-commerce sites (Al-Debei et al., 2015). We thus expect that an e-commerce site, which exhibits service delivery quality, will enhance consumers' perception of website appeal:

Hypothesis 5: Service delivery quality of an e-commerce site positively influences its website appeal.

\subsubsection{Enjoyment}

Whereas service content and delivery quality reflect the utilitarian aspect of website quality (Tan et al., 2013), an e-commerce site can also signal hedonic elements to enhance its website appeal. According to Davis and Bagozzi (1992), enjoyment, in relation to technology, refers to the degree to which "using the [technology] is perceived to be enjoyable in its own right, apart from any performance consequences that may be anticipated" (p. 1113). In this study, we defined enjoyment as consumers 'perception that their activities on an e-commerce site are pleasurable. It represents the affective dimension of e-commerce service quality that supplements any anticipated utilitarian outcomes (Parboteeah et al., 2009). Davis and Bagozzi (1992) found that enjoyment fosters users' positive attitudes toward technology. Enjoyment has also been validated as an important antecedent of individuals' favorable attitudes towards online banking (Pikkarainen et al., 2004), learning (Saadé and Bahli, 2005), and retailing (Ahn et al., 2007, Huang, 2016). We therefore expect that a highly enjoyable e-commerce site will increase consumers' perception of website appeal:

Hypothesis 6: Enjoyment of an e-commerce site positively influences its website appeal. 


\subsection{Antecedents of Product Appeal}

Signals related to product quality can be communicated to consumers via productoriented functionalities implemented by an e-commerce site. These signals, in turn, can mitigate information asymmetry inherent in e-commerce transactions and bolster consumers' perceptions of product appeal (or quality) (Kirmani and Rao, 2000).

Connolly and Zeelenberg (2002) advanced the Decision Justification Theory (DJT) to explain why consumers regret their decisions. DJT postulates two essential components of decisional regret: (1) cognitive evaluation of a decision against select criteria, and; (2) affective attribution of self-blame for making erroneous choices (Connolly and Zeelenberg, 2002). In accordance with DJT, two types of product quality related signals can be conveyed to facilitate consumers' cognitive evaluation of their decisions and relieve their feeling of self-blame.

\subsubsection{Diagnosticity}

The first type of signal is diagnosticity, which refers to consumers' belief regarding the degree to which the shopping experience facilitates their evaluation of product quality (Kempf and Smith, 1998). In line with DJT, a high level of diagnosticity facilitates consumers' cognitive evaluation of a given product, thereby enhancing their perception of product appeal (Connolly and Zeelenberg, 2002). In prior research, perceived diagnosticity has been found to be positively associated with consumers' cognitive evaluation of product quality (Jiang and Benbasat, 2007a; Kempf and Smith, 1998). E-commerce sites may convey signals about product diagnosticity to consumers in order to improve the latter's confidence in assessing products, reduce their perceptions of product risk, and generate positive attitudes towards products listed on the sites (Jiang and Benbasat, 2004; Kempf and Smith, 1998). An ecommerce site can emit signals of diagnosticity by delivering Virtual Product Experience (VPE) to allow consumers to remotely inspect product offerings (Jiang and Benbasat, 2004). VPE can be realized through the implementation of: (1) interactive visual controls (which enable 
consumers to manipulate product images through moving, rotating, as well as zooming in and out of product images), and; (2) functional controls (which permit consumers to explore and experience different product features or functions). Arguably, the diagnosticity of consumers' shopping experience can be bolstered by elevating their knowledge of products listed on the ecommerce site (Huang, 2016; Lee and Choeh, 2016), which in turn enhances the product appeal of the site:

Hypothesis 7: Perceived diagnosticity of consumers' shopping experience on an e-commerce site positively influences its product appeal.

\subsubsection{Justifiability}

The second type of signal related to product quality concerns the notion of justifiability, which refers to consumers' perception that a choice was made "on a defensible basis, supported by convincing arguments or using a thoughtful, comprehensive decision process" (Reb and Connolly, 2010, p. 1405). Reb and Connolly (2010) confirmed that perceptions of decision justifiability significantly reduces the intensity of consumers' anticipated regret even when they were confronted with undesirable outcomes arising from their decisions. An ecommerce site can emit signals of justifiability through multiple means (e.g., positive usergenerated reviews and recommendations) to alleviate consumers' feeling of self-blame and induce positive sentiments towards products of interest (Connolly and Zeelenberg, 2002). We therefore expect that a high level of decision justifiability will increase consumers' perception of product appeal on an e-commerce site:

Hypothesis 8: Perceived justifiability of potential purchase decisions made on an e-commerce site positively influences its product appeal.

\subsection{Direct and Moderating Influence of Trust}

Past studies have examined trust as an indicator of mitigated moral hazard that arises from information asymmetry in e-commerce (Aiken and Boush, 2006; Biswas and Biswas, 2004; Kim et al., 2004). Trust is "a psychological state comprising the intention to accept vulnerability based on positive expectations of the intentions or behaviors of another" 
(Rousseau et al., 1998, p. 395). Trust is a critical aspect of e-commerce transactions because consumers generally lack the means to properly assess e-retailers' dependability and integrity. Continuous two-way interaction, which is central to trust-building, is hindered in online setting (Reichheld and Schefter, 2000). Trust has a positive impact on consumers' purchase intention by: (1) ruling out e-retailers' opportunistic behavior during online transactions, and; (2) reducing the complexity in consumers' decision making process (Gefen et al., 2003b). To build trust, an e-commerce site may signal its trustworthiness to reduce consumers' risk perceptions and increase their purchase intentions (Jarvenpaa et al., 2000). Examples of trustworthiness signals include advertising investments (Aiken and Boush, 2006; Biswas and Biswas, 2004), reputation systems (Biswas and Biswas, 2004; Kim et al., 2004), third-party endorsements (Aiken and Boush, 2006; Biswas and Biswas, 2004), and warranties (Aiken and Boush, 2006). The positive influence of trust on consumers' purchase intentions has been consistently validated in prior research (Gefen et al., 2003b). Thus, we hypothesize that:

Hypothesis 9: Trust in an e-commerce site positively influences consumers' purchase intention.

Signals are not always reliable. False signaling refers to the mismatch between the quality conveyed by a signal and the true underlying quality of an entity (Kirmani and Rao, 2000). Consistent with warranting theory (Walther and Parks, 2002), consumers' trust in an ecommerce site, induced by trustworthiness signals, will boost their confidence in the accuracy of quality signals conveyed by an e-commerce site to communicate the unobservable quality of the site and its product offerings (Lu et al., 2016). Trustworthiness signals thus enhance the positive effects of quality signals on consumers' intention to purchase from the site. Accordingly, we expect that trust in an e-commerce website will reinforce the positive effects of product and website appeal on consumers' purchase intentions:

Hypothesis 10: Trust in an e-commerce site reinforces the positive relationship between website appeal and consumers' purchase intention. 
Hypothesis 11: Trust in an e-commerce site reinforces the positive relationship between product appeal and consumers' purchase intention.

\section{RESEARCH METHOD}

To validate our hypothesized relationships, data was gathered via an online survey questionnaire to elicit consumers' beliefs and attitudes in an e-commerce context.

\subsection{Measurement Development}

We derived the measurement items for our survey questionnaire based on an extensive review of extant literature. All measurement items are reflective, meaning that they are affected by the underlying latent construct being measured (Petter et al., 2007). Measures for purchase intention were adapted from Adelaar et al. (2003) and Bart et al. (2005). Adhering to standard psychometric procedures and consistent with the theorization of appeal in advertising literature (Yeshin, 1998), we developed measures for both product and website appeal. Trust was measured via items adapted from Cyr et al. (2009) and Hassanein and Head (2006). Whereas measures for service content quality, service delivery quality, and enjoyment were elicited from Hampton-Sosa and Koufaris (2005), diagnosticity was measured by items obtained from Jiang and Benbasat (2004, 2007a). Finally, we developed measures for justifiability according to Reb and Connolly's (2010) work on decision justifiability. Table 1 summarizes the measurement items employed in the present study.

\subsection{Survey Administration}

With assistance from a marketing research firm, we recruited 423 members from a panel of existing e-commerce consumers to participate in our survey via invitation emails. Each respondent was rewarded with points that could be utilized to trade for gift vouchers or other prizes. We were able to diversify the demographic makeup of our sample and ensure that each respondent answered the questionnaire based on their shopping experience on an e-commerce site they frequented in the past six months. Among the 423 responses, 130 responses were 
discarded due to incomplete answers, leaving a final sample of 293 valid data points for analysis. Descriptive statistics of the sample are summarized in Table 2.

To confirm that nonresponse bias is not a threat to our data analysis, we conducted chisquare test between our sample demographics and those documented in Tan et al. (2016). As depicted in Table 2, the demographic distribution is comparable across the two studies, indicating that our sample was not plagued by nonresponse bias.

\section{- Insert Table 1 here -}

\section{DATA ANALYSIS AND RESULTS}

SmartPLS 2.0.M3 (Ringle et al., 2005) was employed to validate the measurement and structural properties of our research model (Hair et al., 2010). The size of our sample (i.e., 293) well surpasses the minimum threshold required by SmartPLS 2.0 M3, which is five times the number of indicators of the construct with most indicators (i.e., 100) (Hair Jr et al., 2016).

\subsection{Measurement Model}

All loadings of measurement items on their corresponding constructs exceed 0.7 (see Table 1). Furthermore, the Cronbach's alpha and composite reliability of each construct are higher than 0.7, indicating satisfactory internal consistency (see Table 3).

\section{- Insert Table 2 here -}

Table 1 shows that items display high factorial loadings on the construct they are supposed to measure (above recommended threshold of 0.7) (Hair et al., 2010) and low factorial loadings on unrelated constructs. Moreover, the items demonstrate discriminant validity since: (1) no problem with cross-loading exists; (2) the Average Variance Extracted (AVE) for each construct exceeds the threshold of 0.5 (see Table 3) (Fornell and Larcker, 1981), and; (3) the square-root of the AVE for each construct is greater than its correlation with any other construct (see Table 3).

\section{- Insert Table 3 here -}


Common Method Bias (CMB) was first assessed by applying Harman's single-factor test (Podsakoff et al., 2003) and result suggests that CMB is not a threat to our study. We then applied the statistical remedy for common method bias (Podsakoff et al., 2003) by introducing a non-related latent method factor into our structural model to account for the plausible influence of common method. Results indicate that the statistical significance of the path coefficients remain relatively constant (see Figure 1).

\subsection{Structural Model}

Hypothesized relationships in our research model were validated through PLS analysis. Figure 1 depicts the analytical result of our structural model ${ }^{2}$.

As depicted in Figure 1, both website appeal $(\beta=0.433, p<0.001)$ and product appeal $(\beta=0.100, p<0.1)$ exert significant positive effects on consumers' purchase intention. As predicted, service delivery quality $(\beta=0.086, p<0.01)$, enjoyment $(\beta=0.289, p<0.001)$, and product appeal $(\beta=0.509, p<0.001)$ have positive and significant impact on website appeal. Likewise, diagnosticity $(\beta=0.339, p<0.001)$ and justifiability $(\beta=0.289, p<0.001)$ positively influence product appeal. Finally, the positive relationship between trust and purchase intention $(\beta=0.187, p<0.001)$ as well as the reinforcing effect of trust $(\beta=0.189, p<0.001)$ on the relationship between website appeal and purchase intention are corroborated. Contrary to our expectations, however, the positive relationship between service content quality and website appeal is non-significant. Trust also exhibits an unexpected negative moderating effect $(\beta=-$ $0.147, p<0.05)$ on the relationship between product appeal and purchase intention. With the exception of Hypotheses 4 and 11, all our hypotheses are substantiated by the empirical evidence.

\section{- Insert Figure 1 here -}

\footnotetext{
${ }^{2}$ Standard errors were calculated by using a bootstrapping process with 500 resamples.
} 


\subsection{Unexpected Findings}

We conducted post-hoc analysis to explore why the relationship between service content quality and website appeal is non-significant. We analyzed an alternative model by removing the path from product appeal to website appeal (see Figure 2), which gave rise to additional insights. First, the relationship between service content quality and website appeal becomes significantly positive $(\beta=0.212, p<0.001)$. Also, the positive effects of both service delivery quality $(\beta=0.161, p<0.001)$ and enjoyment $(\beta=0.492, p<0.001)$ on website appeal are strengthened. Finally, the variance explained in website appeal decreases from $66.9 \%$ to $54.5 \%$. These findings suggest that product appeal may have partially accounted for consumers' assessment of service delivery quality and enjoyment while accounting fully for the impact of service content quality on website appeal (Huang, 2016). Since the value of an e-commerce site lies in its ability to facilitate consumers' online shopping, we submit that any e-commerce site is only as appealing as its listed products. While the provision of functionalities supporting product acquisition (i.e., e-commerce service content) is important, it only matters if the ecommerce site is able to support consumers in making purchase decisions. Results of pseudo$F$ test exposes that the variance explained in website appeal is significantly reduced when the effect of product appeal is excluded (see Table 4). Additional pseudo- $F$ tests reveal that, while the variance explained in purchase intention decreases significantly when the effect of website appeal is excluded from data analysis, excluding product appeal will not lead to a significant drop in the variance explained in purchase intention (see Table 4). Taken together, the aforementioned results imply that although product appeal does not significantly affect purchase intention, it is a salient predictor of website appeal while impacting purchase intention indirectly.

- Insert Figure 2 here -

- Insert Table 4 here - 


\section{DISCUSSION}

This study yields several unexpected findings. First, there is no discernible relationship between service content quality and website appeal, and supplementary analysis reveals that the effect of service content quality on website appeal is suppressed by product appeal. Second, trust is found to attenuate (rather than reinforce) the positive effect of product appeal on purchase intention. Due to the positive relationship between consumers' familiarity with an ecommerce site and their trust in this site (Kim et al., 2008), the unexpected negative moderating effect of trust may be explained by the reduced tendency of experienced consumers with high trust in an e-commerce site (Gefen et al., 2003a) to carefully assess products listed on the site prior to purchase. In contrast, inexperienced consumers with low trust in an e-commerce site (Jarvenpaa et al., 2000) might rely on product-oriented functionalities to a greater extent in order to alleviate their concerns about product risk.

\subsection{Implications for Theory and Practice}

This study contributes to e-commerce research on three fronts. First, extending signaling theory, we draw on the concept of appeal from advertising literature to not only distinguish between product and website appeal in order to capture consumers' positive interpretation of product- and service-related qualities signaled by e-commerce sites, but to also investigate the effects of both product and website appeal on online consumption. Compared to past studies that concentrate primarily on website appeal (Campbell et al., 2013; Tamimi and Sebastianelli, 2015; Wells et al., 2011), we demonstrate that the appeal of e-commerce sites is not founded solely on the availability of functionalities to aid consumers in product acquisition. Rather, consumers also take into account whether products offered on the site are appealing. Consequently, an alternate way of enhancing website appeal is to bolster the appeal of listed products over and beyond improving acquisition functionalities. Moreover, in contrast to prior research that alluded to the criticality of product appeal (e.g., Wang et al., 2016), findings from 
our study also suggest that product appeal, by itself, does not drive purchase intentions. Enhancing the appeal of products may not encourage consumer purchase if e-commerce sites do not offer complementary functionalities that facilitate the product acquisition process. Our study thus expands on extant literature by establishing both product and website appeal as indispensable drivers of consumers' purchase intention in e-commerce.

Second, we have identified five quality related factors from prior research that can be signaled by e-commerce sites to enhance their product and website appeal. While service content quality, service delivery quality, and enjoyment embody utilitarian and hedonic aspects of e-commerce service quality, diagnosticity and justifiability are synonymous with cognitive and emotional cues aimed at conveying product-related qualities. Results reveal that these qualities can significantly enhance consumers' perception of product and website appeal, thereby culminating in their increased intention to purchase from e-commerce sites.

Finally, guided by warranting theory (Walther and Parks, 2002), our inquiry into the moderating role of trust unveiled that while consumers' trust in e-commerce sites intensifies the positive influence of website appeal on their purchase intention (by building consumers' confidence in the reliability of signals), it concurrently mitigates the positive impact of product appeal on purchase intention. This could be due to the inclination of experienced shoppers to refrain from in-depth evaluation of product quality before purchase. This is a novel observation that has not been reported in past studies, and it sheds light on the differential role trust plays in moderating the relationships between the two types of appeal and purchase intention.

Our findings also offer invaluable insights to practitioners by sensitizing them to strategies that can be formulated to enhance consumers' perceptions of product and website appeal. Employing our theoretical model as guiding principles, e-retailers can better channel their resources to signal qualities most pertinent to product and website appeal. For example, to bolster consumers' perceptions of website appeal, e-commerce sites could: (1) offer 
sophisticated product search features to ensure high service content quality; (2) provide navigation guidance to induce high service delivery quality, and; (3) elaborate on product recommendations to heighten enjoyment. Furthermore, because product appeal (e.g., whether products are presented in an appealing manner) shapes consumers' assessment of the service content quality of e-commerce sites as uncovered through our post-hoc analysis, e-commerce sites should offer product-oriented functionalities (e.g., virtual product presentation) to induce product appeal, especially for those consumers who have yet to trust the sites. Lastly, in light of the unique role trust plays in reinforcing the effect of website appeal while attenuating the impact of product appeal on purchase intention (Lu et al., 2016), e-commerce sites can attract new consumers with product-oriented functionalities that render products more appealing while retaining existing ones by making it easier and more enjoyable for them to source for and acquire desired products.

\subsection{Limitations and Future Research}

There are two caveats in our study that should be addressed in future research. First, this study does not explicitly prescribe actionable design guidelines. Because prior research has already highlighted actionable design guidelines for realizing product and website appeal (Wells et al., 2011), these guidelines can be combined with our empirical findings to generate design prescriptions for enhancing the appeal of e-commerce sites. Second, online purchase behavior can be investigated from a diversity of theoretical viewpoints (Van Der Heijden et al., 2003). In the present study, we attempted to construct a parsimonious research model by building on the signaling theory. While our research model explained $49.4 \%$ of the variance in consumers' purchase intention, we still urge future studies to explore online consumption through other theoretical lenses in order to proffer a more comprehensive and holistic appreciation of this phenomenon. 


\section{REFERENCES}

Adelaar, T., Chang, S., Lancendorfer, K.M., Lee, B. and Morimoto, M. (2003), "Effects of media formats on emotions and impulse buying intent", Journal of Information Technology, Vol. 18 No. 4, pp. 247-266.

Ahn, T., Ryu, S. and Han, I. (2007), "The impact of web quality and playfulness on user acceptance of online retailing”, Information \& Management, Vol. 44 No. 3, pp. 263-275.

Aiken, K.D. and Boush, D.M. (2006), "Trustmarks, objective-source ratings, and implied investments in advertising: Investigating online trust and the context-specific nature of internet signals", Journal of the Academy of Marketing Science, Vol. 34 No. 3, pp. 308-323.

Ajzen, I. and Fishbein, M. (1980), "Understanding attitudes and predicting social", Behaviour. Englewood Cliffs, NJ: Prentice-Hall.

Al-Debei, M.M., Akroush, M.N. and Ashouri, M.I. (2015), "Consumer attitudes towards online shopping: The effects of trust, perceived benefits, and perceived web quality", Internet Research, Vol. 25 No. 5, pp. 707-733.

Ba, S. and Pavlou, P.. (2002), "Evidence of the effect of trust building technology in electronic markets: Price premiums and buyer behavior", MIS Quarterly, Vol. 26 No. 3, pp. 243-268.

Bart, Y., Shankar, V., Sultan, F. and Urban, G.L. (2005), "Are the drivers and role of online trust the same for all web sites and consumers? A large-scale exploratory empirical study", Journal of Marketing, Vol. 69 No. 4, pp. 133-152.

Basuroy, S., Desai, K.K. and Talukdar, D. (2006), "An empirical investigation of signaling in the motion picture industry”, Journal of Marketing Research, Vol. 43 No. 2, pp. 287-295.

Becerra, E.P. and Korgaonkar, P.K. (2011), "Effects of trust beliefs on consumers' online intentions", European Journal of Marketing, Vol. 45 No. 6, pp. 936-962.

Biswas, D. and Biswas, A. (2004), "The diagnostic role of signals in the context of perceived risks in online shopping: Do signals matter more on the web?", Journal of Interactive Marketing, Vol. 18 No. 3, pp. 30-45.

Cai, S., Xu, Y.J., Yu, J. and De Souza, R. (2008), "Understanding aesthetics design for e-commerce web sites: A cognitive-affective framework", 12th Pacific Asia Conference on Information Systems (Pacis 2008), p. Paper 60.

Campbell, D.E., Wells, J.D. and Valacich, J.S. (2013), "Breaking the ice in B2C relationships: Understanding pre-adoption e-commerce attraction", Information Systems Research, Vol. 24 No. 2, pp. 219-238.

Carter, L. and Bélanger, F. (2005), "The utilization of e-government services: Citizen trust, innovation and acceptance factors", Information Systems Journal, Vol. 15 No. 1, pp. 5-25.

Cenfetelli, R.T., Benbasat, I. and Al-Natour, S. (2008), “Addressing the what and how of online services: Positioning supporting-services functionality and service quality for business-to-consumer success", Information Systems Research, Vol. 19 No. 2, pp. 161-181.

Chu, W., Choi, B. and Song, M.R. (2005), "The role of on-line retailer brand and infomediary reputation in increasing consumer purchase intention", International Journal of Electronic Commerce, Vol. 9 No. 3, pp. 115-127. 
Chua, A.Y.K. and Banerjee, S. (2015), "Analyzing users' trust for online health rumors", 17th International Conference on Asia-Pacific Digital Libraries (ICADL 2015), Seoul, Korea, pp. 3338.

Connelly, B.L., Certo, S.T., Ireland, D. and Reutzel, C.R. (2010), "Signaling theory: A review and assessment", Journal of Management, Vol. 37 No. 1, pp. 39-67.

Connolly, T. and Zeelenberg, M. (2002), "Regret in decision making", Current Directions in Psychological Science, Vol. 11 No. 6, pp. 212-216.

Cyr, D., Head, M., Larios, H. and Pan, B. (2009), "Exploring human images in website design: A multimethod approach", MIS Quarterly, Vol. 33 No. 3, pp. 539-566.

Davis, F. and Bagozzi, R. (1992), "Extrinsic and intrinsic motivation to use computers in the workplace1", Journal of Applied Social, Vol. 22 No. 14, pp. 1111-1132.

Dean, D.H. and Biswas, A. (2001), "Third-party organization endorsement of products: An advertising cue affecting consumer prepurchase evaluation of goods and services", Journal of Advertising, Vol. 30 No. 4, pp. 41-57.

Dimoka, A., Hong, Y. and Pavlou, P.A. (2012), "On product uncertainty in online markets: Theory and evidence”, MIS Quarterly, Vol. 36 No. 2, pp. 395-426.

Fornell, C. and Larcker, D.F. (1981), "Evaluating structural equation models with unobservable variables and measurement error", Journal of Marketing Research, Vol. 18 No. 1, pp. 39-50.

Gefen, D. (2000), “E-commerce: The role of familiarity and trust”, Omega, Vol. 28 No. 6, pp. 725-737.

Gefen, D. (2002a), "Reflections on the dimensions of trust and trustworthiness among online consumers", ACM Sigmis Database, Vol. 33 No. 3, pp. 38-53.

Gefen, D. (2002b), "Customer loyalty in e-commerce", Journal of the Association for Information Systems, Vol. 3 No. 1, pp. 27-51.

Gefen, D., Karahanna, E. and Straub, D.W. (2003a), "Inexperience and experience with online stores: The importance of TAM and trust", Ieee Transactions on Engineering Management, Vol. 50 No. 3, pp. 307-320.

Gefen, D., Karahanna, E. and Straub, D.W. (2003b), "Trust and TAM in online shopping: An integrated mode", MIS Quarterly, Vol. 27 No. 1, pp. 51-90.

Gefen, D. and Straub, D.W. (2000), "The relative importance of perceived ease of use in is adoption: A study of e-commerce adoption", Journal of the Association for Information Systems, Vol. 1 No. 1, pp. 1-28.

Gregg, D.G. and Walczak, S. (2008), "Dressing your online auction business for success: An experiment comparing two eBay businesses", MIS Quarterly, Vol. 32 No. 3, pp. 653-670.

Grönroos, C. (1984), "A service quality model and its marketing implications", European Journal of Marketing, Vol. 18 No. 4, pp. 36-44.

Grönroos, C., Heinonen, F., Isoniemi, K. and Lindholm, M. (2000), "The NetOffer model: A case example from the virtual marketplace", Management Decision, Vol. 38 No. 4, pp. 243-252.

Hair, J.F., Black, W.C., Babin, B.Y. and Anderson, R.E. (2010), Multivariate Data Analysis - a Global Perspective, 5th ed., Pearson Prentice Hall, Upper Saddle River. 
Hair Jr, J.F., Hult, G.T.M., Ringle, C. and Sarstedt, M. (2016), A Primer on Partial Least Squares Structural Equation Modeling (PLS-SEM), Sage Publications.

Hampton-Sosa, W. and Koufaris, M. (2005), "The effect of web site perceptions on initial trust in the owner company", International Journal of Electronic Commerce, Vol. 10 No. 1, pp. 55-81.

Hassanein, K. and Head, M. (2006), "The impact of infusing social presence in the web interface: An investigation across product types", International Journal of Electronic Commerce, Vol. 10 No. 2, pp. 31-55.

Huang, L. T. (2016). "Exploring utilitarian and hedonic antecedents for adopting information from a recommendation agent and unplanned purchase behaviour," New Review of Hypermedia and Multimedia, Vol. 22, No. (1-2), pp. 139-165.

Van Der Heide, B., Johnson, B.K. and Vang, M.H. (2013), "The effects of product photographs and reputation systems on consumer behavior and product cost on eBay", Computers in Human Behavior, Vol. 29 No. 3, pp. 570-576.

Van Der Heijden, H., Verhagen, T. and Creemers, M. (2003), "Understanding online purchase intentions: Contributions from technology and trust perspectives", European Journal of Information Systems, Vol. 12 No. 1, pp. 41-48.

Jahng, J., Jain, H. and Ramamurthy, K. (2007), "Effects of interaction richness on consumer attitudes and behavioral intentions in e-commerce: Some experimental results", European Journal of Information Systems, Vol. 16 No. 3, pp. 254-269.

Janda, S., Trocchia, P.J. and Gwinner, K.P. (2002), "Consumer perceptions of Internet retail service quality”, International Journal of Service Industry Management, Vol. 13 No. 5, pp. 412-431.

Janney, J.J. and Folta, T.B. (2003), "Signaling through private equity placements and its impact on the valuation of biotechnology firms", Journal of Business Venturing, Vol. 18 No. 3, pp. 361-380.

Janney, J.J. and Folta, T.B. (2006), "Moderating effects of investor experience on the signaling value of private equity placements", Journal of Business Venturing, Vol. 21 No. 1, pp. $27-44$.

Jarvenpaa, S.L., Tractinsky, N. and Vitale, M. (2000), "Consumer trust in an Internet store", Information Technology and Management, Vol. 1 No. 2, pp. 45-71.

Javornik, A. (2016). "Augmented reality: Research agenda for studying the impact of its media characteristics on consumer behaviour," Journal of Retailing and Consumer Services, Vol. 30, pp. 252-261.

Jiang, Z. and Benbasat, I. (2004), "Virtual product experience: Effects of visual and functional control of products on perceived diagnosticity and flow in electronic shopping", Journal of Management Information Systems, Vol. 21 No. 3, pp. 111-147.

Jiang, Z. and Benbasat, I. (2007a), "Research note-investigating the influence of the functional mechanisms of online product presentations", Information Systems Research, Vol. 18 No. 4, pp. $454-470$.

Jiang, Z. and Benbasat, I. (2007b), "The effects of presentation formats and task complexity on online consumers' product understanding”, MIS Quarterly, Vol. 31 No. 3, pp. 497-520.

Jiang, Z., Chan, J., Tan, B. and Chua, W. (2010), "Effects of interactivity on website involvement and purchase intention", Journal of the Association for Information Systems, Vol. 11 No. 1, pp. 34- 
59.

Johar, J.S. and Sirgy, M.J. (1991), "Value-expressive versus utilitarian advertising appeals: When and why to use which appeal", Journal of Advertising, Vol. 20 No. 3, pp. 23-33.

Kempf, D.S. and Smith, R.E. (1998), "Consumer processing of product trial and the influence of prior advertising: A structural modeling approach", Journal of Marketing Research, Vol. 35 No. 3, p. 325.

Kim, D.J., Ferrin, D.L. and Rao, H.R. (2008), “A trust-based consumer decision-making model in electronic commerce: The role of trust, perceived risk, and their antecedents", Decision Support Systems, Vol. 44 No. 2, pp. 544-564.

Kim, H.-W., Xu, Y. and Koh, J. (2004), “A comparison of online trust building factors between potential customers and repeat customers", Journal of the Association for Information Systems, Vol. 5 No. 10, pp. 392-420.

Kirmani, A. and Rao, A.R. (2000), "No pain, no gain: A critical review of the literature on signaling unobservable product quality", Journal of Marketing, Vol. 64 No. 2, pp. 66-79.

Kollock, P. (1999), “The economies of online cooperation”, Communities in Cyberspace, Vol. 220, pp. 259-262.

Komiak, S.Y.X. and Benbasat, I. (2006), "The effects of personalization and familiarity on trust and adoption of recommendation agents", MIS Quarterly, Vol. 30 No. 4, pp. 941-960.

Lee, S. and Choeh, J.Y. (2016), "The determinants of helpfulness of online reviews," Behaviour and Information Technology, Vol. 35, No. 10, pp. 853-863.

Lee, J.-N., Pi, S.-M., Kwok, R.C. and Huynh, M.Q. (2003), "The contribution of commitment value in Internet commerce: An empirical investigation", Journal of the Association for Information Systems, Vol. 4 No. 1, pp. 39-64.

Lu, B., Fan, W., and Zhou, M. (2016). "Social presence, trust, and social commerce purchase intention: An empirical research." Computers in Human Behavior, Vol. 56, pp. 225-237.

Michael, S.C. (2009), "Entrepreneurial signaling to attract resources: The case of franchising", Managerial and Decision Economics, Vol. 30 No. 6, pp. 405-422.

Özpolat, K. and Jank, W. (2015), "Getting the most out of third party trust seals: An empirical analysis", Decision Support Systems, Vol. 73, pp. 47-56.

Parboteeah, D.V., Valacich, J.S. and Wells, J.D. (2009), "The influence of website characteristics on a consumer's urge to buy impulsively", Information Systems Research, Vol. 20 No. 1, pp. 60-78.

Pavlou, P., Liang, H. and Xue, Y. (2007), "Understanding and mitigating uncertainty in online exchange relationships: A principal-agent perspective”, MIS Quarterly, Vol. 31 No. 1, pp. 105-136.

Petter, S., Straub, D. and Rai, A. (2007), "Specifying formative constructs in information systems research", MIS Quarterly, Vol. 31 No. 4, pp. 623-656.

Podsakoff, P.M., MacKenzie, S.B., Lee, J.Y. and Podsakoff, N.P. (2003), "Common method biases in behavioral research: A critical review of the literature and recommended remedies", Journal of Applied Psychology, Vol. 88 No. 5, pp. 879-903.

Rahimnia, F. and Hassanzadeh, J.F. (2013), "The impact of website content dimension and e-trust on 
e-marketing effectiveness: The case of Iranian commercial saffron corporations", Information and Management, Vol. 50 No. 5, pp. 240-247.

Rao, A.R., Qu, L. and Ruekert, R.W. (1999), "Signaling unobservable product quality through a brand ally", Journal of Marketing Research, Vol. 36 No. 2, pp. 258-268.

Reb, J. and Connolly, T. (2010), "The effects of action, normality, and decision carefulness on anticipated regret: Evidence for a broad mediating role of decision justifiability", Cognition and Emotion, Vol. 24 No. 8, pp. 1405-1420.

Reichheld, F.F. and Schefter, P. (2000), "E-loyalty”, Harvard Business Review, Vol. 78 No. 4, pp. 105113.

Riel, A.C.R. Van, Liljander, V. and Jurriëns, P. (2001), "Exploring consumer evaluations of e-services: A portal site", International Journal of Service Industry Management, Vol. 12 No. 4, pp. 359-377.

Ringle, C.M., Wende, S. and Will, A. (2005), "SmartPLS (Release 2.0 M3) http://www. smartpls. de. University of Hamburg", Hamburg: Germany.

Rousseau, D.M., Sitkin, S.B., Burt, R.S. and Camerer, C. (1998), "Not so different after all: A crossdiscipline view of trust", Academy of Management Review, Vol. 23 No. 3, pp. 393-404.

Saadé, R. and Bahli, B. (2005), "The impact of cognitive absorption on perceived usefulness and perceived ease of use in on-line learning: An extension of the technology acceptance model", Information \& Management, Vol. 42 No. 2, pp. 317-327.

Sánchez-Hernández, R.M., Martínez-Tur, V., Peiró, J.M. and Ramos, J. (2009), “Testing a hierarchical and integrated model of quality in the service sector: Functional, relational, and tangible dimensions", Total Quality Management, Vol. 20 No. 11, pp. 1173-1188.

Song, J. and Zahedi, F. "Mariam". (2007), “Trust in health infomediaries”, Decision Support Systems, Vol. 43 No. 2, pp. 390-407.

Spence, B.M. (2014), "Signaling in retrospect and the informational structure of markets", American Economic Review, Vol. 92 No. 3, pp. 434-459.

Spence, M. (1973), “Job market signaling”, The Quarterly Journal of Economics, Vol. 87 No. 3, pp. 355-374.

Tamimi, N. and Sebastianelli, R. (2015), "The relative importance of e-tailer website attributes on the likelihood of online purchase", Internet Research, Vol. 25 No. 2, pp. 169-183.

Tan, C.-W., Benbasat, I. and Cenfetelli, R.T. (2016), "An exploratory study of the formation and impact of electronic service failures”, MIS Quarterly, Vol. 40 No. 1, pp. 1-29.

Tan, C., Benbasat, I. and Cenfetelli, R. (2013), "IT-mediated customer service content and delivery in electronic governments: An empirical investigation of the antecedents of service quality", $M I S$ Quarterly, Vol. 37 No. 1, pp. 77-109.

Walther, J.B. and Parks, M.R. (2002), "Cues filtered out, cues filtered in: Computer-mediated communication and relationships", Handbook of Interpersonal Communication, Vol. 3 No. 1, pp. $529-563$.

Wang, Q., Cui, X., Huang, L. and Dai, Y. (2016), "Seller reputation or product presentation? An empirical investigation from cue utilization perspective", International Journal of Information Management, Vol. 36 No. 3, pp. 271-283. 
Wells, J., Valacich, J. and Hess, T. (2011), "What signals are you sending? How website quality influences perceptions of product quality and purchase intentions", MIS Quarterly, Vol. 35 No. 2, pp. 373-396.

Williams, J.C. (2013), "Online Shoppers and Buyers - White Paper", available at: http://www.jcwg.com/contents_supporters/library_files/Canada Post Online Shoppers and Buyers White Paper.pdf.

Xiao, B. and Benbasat, I. (2011), "Product-related deception in e-commerce: A theoretical perspective", MIS Quarterly, Vol. 35 No. 1, pp. 169-196.

Yeshin, T. (1998), Integrated Marketing Communications: The Holistic Approach, 3rd ed., Butterworth Heinemann, Burlington.

Zeithaml, V.A., Parasuraman, A. and Malhotra, A. (2000), “A conceptual framework for understanding e-service quality: Implications for future research and managerial practice", Report- Marketing Science Institute Cambridge Massachusetts, No. 115, pp. 1-49.

\section{Figures and Tables}

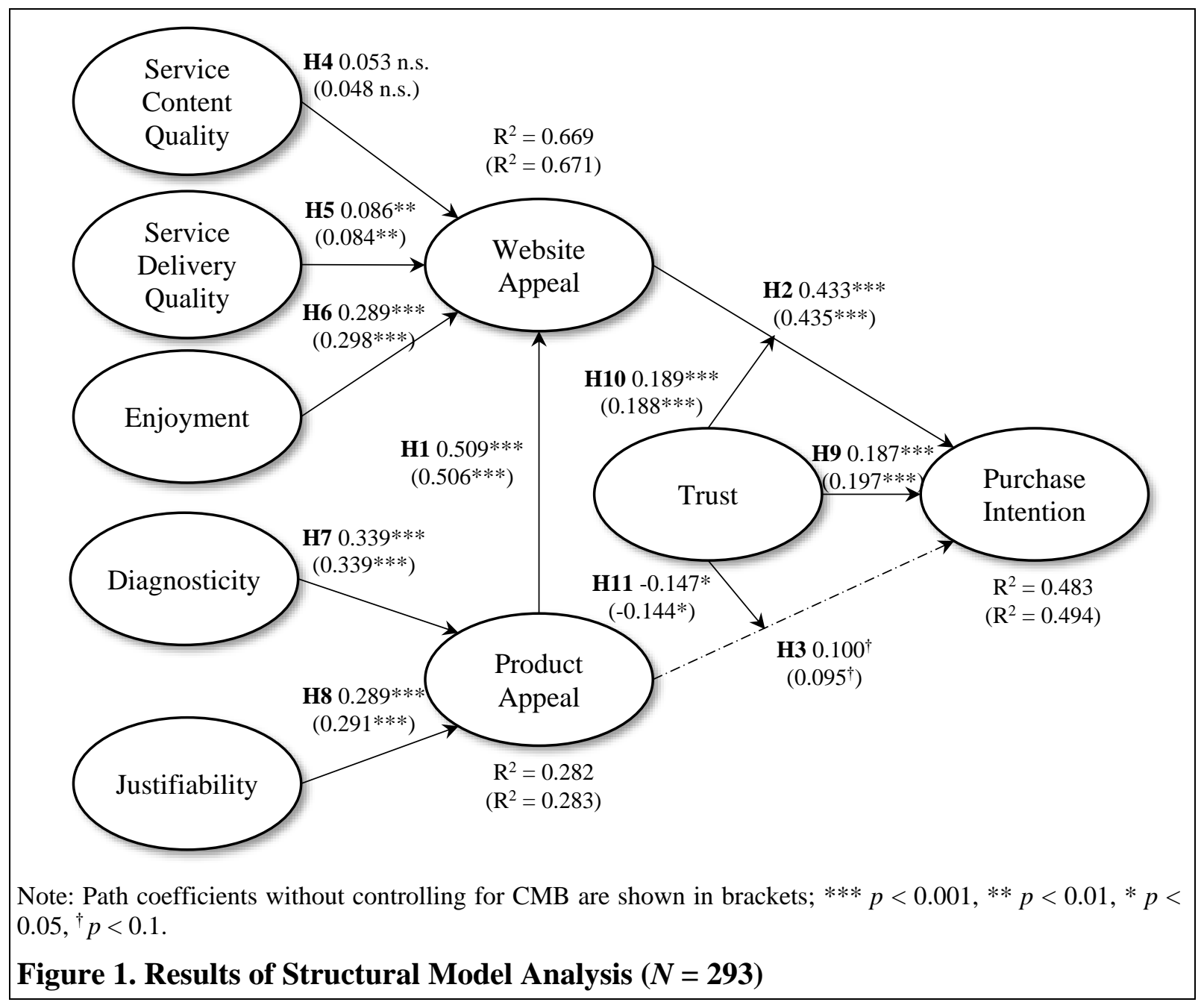




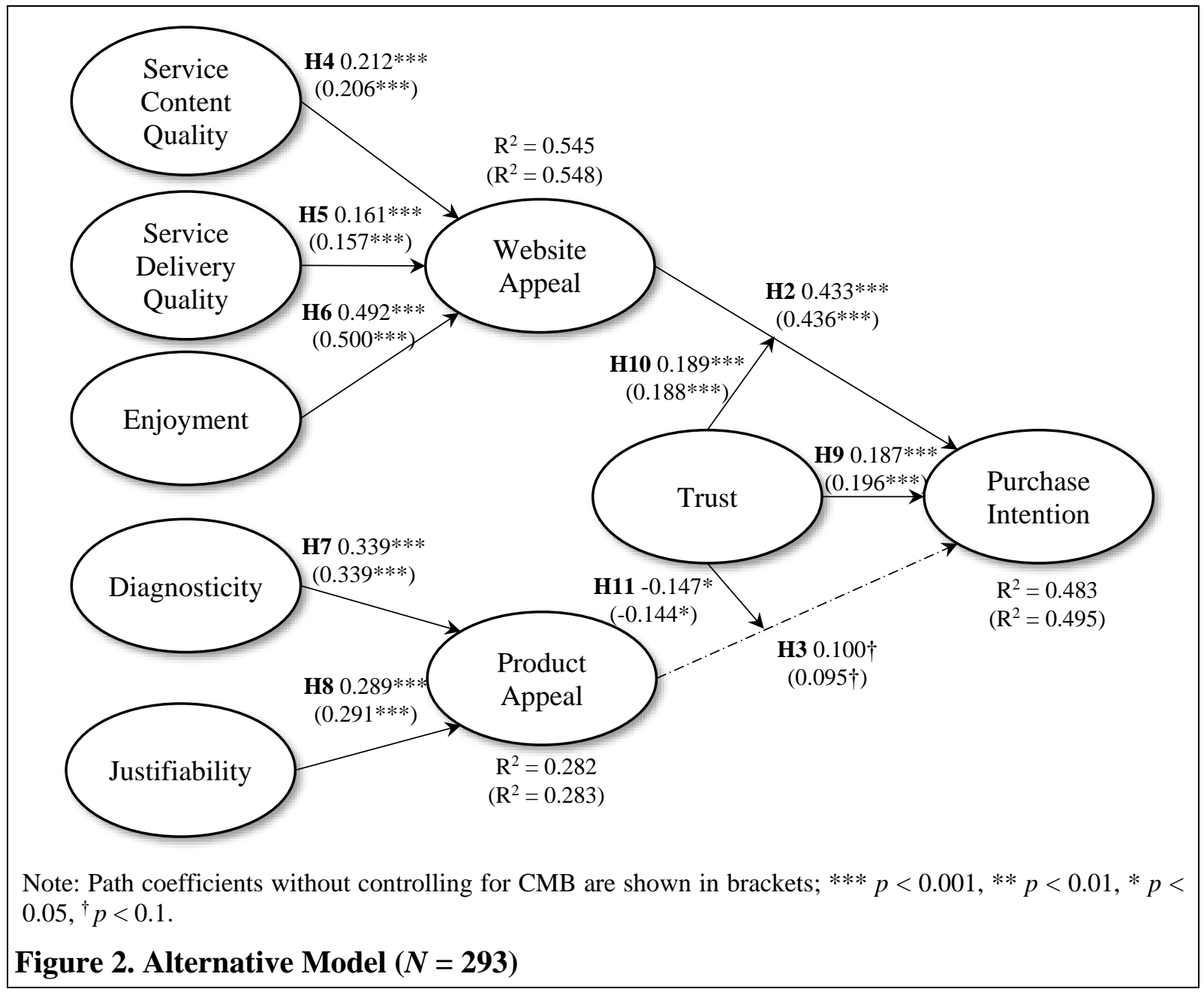




\begin{tabular}{|c|c|c|}
\hline Construct & Measurement Items (7-point Likert scale) & Loading \\
\hline \multirow{3}{*}{$\begin{array}{l}\text { Purchase } \\
\text { Intention (PI) }\end{array}$} & I intend to (once again) make a purchase from the website (Adelaar et al., 2003). & 0.938 \\
\hline & I would (once again) make a purchase from the website (Bart et al., 2005). & 0.917 \\
\hline & I plan to (once again) make a purchase from the website. & 0.929 \\
\hline \multirow{4}{*}{$\begin{array}{l}\text { Website Appeal } \\
\text { (WA) }\end{array}$} & Shopping on the website is appealing. & 0.913 \\
\hline & Shopping on the website is pleasing. & 0.943 \\
\hline & Shopping on the website is attractive. & 0.909 \\
\hline & Shopping on the website is charming. & 0.934 \\
\hline \multirow{4}{*}{$\begin{array}{l}\text { Product Appeal } \\
\text { (PA) }\end{array}$} & Products offered on the website are appealing. & 0.911 \\
\hline & Products offered on the website are pleasing. & 0.942 \\
\hline & Products offered on the website are attractive. & 0.930 \\
\hline & Products offered on the website are charming. & 0.937 \\
\hline \multirow{5}{*}{ Trust (TR) } & I trust the website (Cyr et al., 2009). & 0.926 \\
\hline & I trust the information presented on the website (Cyr et al., 2009). & 0.914 \\
\hline & I trust the transaction process on the website (Cyr et al., 2009). & 0.920 \\
\hline & I feel that the website is honest (Hassanein and Head, 2006). & 0.906 \\
\hline & I feel that the website is trustworthy (Hassanein and Head, 2006). & 0.907 \\
\hline \multirow{3}{*}{$\begin{array}{l}\text { Service Content } \\
\text { Quality (SCQ) }\end{array}$} & $\begin{array}{l}\text { Using the website can improve my shopping performance (Hampton-Sosa and } \\
\text { Koufaris, 2005). }\end{array}$ & 0.932 \\
\hline & $\begin{array}{l}\text { Using the website can increase my shopping productivity (Hampton-Sosa and } \\
\text { Koufaris, 2005). }\end{array}$ & 0.968 \\
\hline & $\begin{array}{l}\text { Using the website can increase my shopping effectiveness (Hampton-Sosa and } \\
\text { Koufaris, 2005). }\end{array}$ & 0.939 \\
\hline \multirow{3}{*}{$\begin{array}{l}\text { Service Delivery } \\
\text { Quality (SDQ) }\end{array}$} & The website is easy to use (Hampton-Sosa and Koufaris, 2005). & 0.956 \\
\hline & $\begin{array}{l}\text { It is easy to become skillful in using the website (Hampton-Sosa and Koufaris, } \\
\text { 2005). }\end{array}$ & 0.963 \\
\hline & Learning to operate the website is easy (Hampton-Sosa and Koufaris, 2005). & 0.960 \\
\hline \multirow{4}{*}{ Enjoyment (EN) } & The website is interesting (Hampton-Sosa and Koufaris, 2005). & 0.926 \\
\hline & The website is enjoyable (Hampton-Sosa and Koufaris, 2005). & 0.904 \\
\hline & The website is fun (Hampton-Sosa and Koufaris, 2005). & 0.934 \\
\hline & The website is entertaining (Hampton-Sosa and Koufaris, 2005). & 0.778 \\
\hline \multirow{3}{*}{$\begin{array}{l}\text { Diagnosticity } \\
\text { (DI) }\end{array}$} & The website offers the ability to evaluate products being offered. & $\mathbf{0 . 9 3 3}$ \\
\hline & $\begin{array}{l}\text { The website offers the ability to evaluate the functionality of the products being } \\
\text { offered. }\end{array}$ & 0.957 \\
\hline & $\begin{array}{l}\text { The website offers the ability to evaluate the appearance of the products being } \\
\text { offered. }\end{array}$ & 0.928 \\
\hline \multirow{3}{*}{ Justifiability (JU) } & I can justify my purchase decision when the purchase is made via the website. & 0.944 \\
\hline & $\begin{array}{l}\text { I feel confident in my purchase decision when the purchase is made via the } \\
\text { website. }\end{array}$ & 0.934 \\
\hline & I can defend my purchase decision when the purchase is made via the website. & 0.946 \\
\hline
\end{tabular}




\begin{tabular}{|c|c|c|c|c|c|c|}
\hline $\begin{array}{l}\text { Demographic } \\
\text { Variable }\end{array}$ & Category & Percentage $(\%)$ & Comparison $^{\dagger}(\%)$ & $x^{2}$ Test $^{\ddagger}$ & E-commerce site Usage $(u)$ & Purcha \\
\hline \multirow{2}{*}{ Gender } & Female & 46.47 & 37.44 & \multirow{2}{*}{$99 \%$} & 3 years $\leq u<4$ years & $f \geq$ on \\
\hline & Male & 53.53 & 62.56 & & 2 years $\leq u<3$ years & $f \geq$ on \\
\hline \multirow{4}{*}{ Age } & $19-29$ & 14.94 & 15.16 & \multirow{4}{*}{$100 \%$} & 2 years $\leq u<3$ years & $f \geq$ on \\
\hline & $30-49$ & 31.54 & 40.76 & & 2 years $\leq u<3$ years & $f \geq$ on \\
\hline & $50-64$ & 38.59 & 33.65 & & 2 years $\leq u<3$ years & $f \geq$ on \\
\hline & Over 65 & 14.94 & 9.48 & & 2 years $\leq u<3$ years & $f \geq$ on \\
\hline \multirow{5}{*}{ Income } & $€ 0-€ 30,000$ & 39.42 & 32.23 & \multirow{5}{*}{$97 \%$} & 2 years $\leq u<3$ years & $f \geq$ on \\
\hline & $€ 30,000-€ 50,000$ & 43.57 & 23.70 & & 3 years $\leq u<4$ years & $f \geq$ on \\
\hline & $€ 50,000-€ 75,000$ & 10.79 & 18.48 & & 3 years $\leq u<4$ years & $f \geq$ on \\
\hline & Over $€ 75,000$ & 6.22 & 20.85 & & 2 years $\leq u<3$ years & $f \geq$ on \\
\hline & Unwilling to disclose & 0.00 & 0.05 & & N/A & \\
\hline \multirow{3}{*}{ Education } & $\begin{array}{l}\text { Less than college } \\
\text { education }\end{array}$ & 81.90 & 23.22 & \multirow{3}{*}{$30 \%$} & 2 years $\leq u<3$ years & $f \geq$ \\
\hline & $\begin{array}{l}\text { College education or } \\
\text { higher }\end{array}$ & 17.40 & 75.83 & & 3 years $\leq u<4$ years & $f$ \\
\hline & Unwilling to disclose & 0.70 & 0.01 & & 1 year $\leq u<2$ years & $f \geq$ \\
\hline
\end{tabular}

\footnotetext{
$\dagger$ Tan et al. (2016)

${ }^{\ddagger}$ Probability of respondents belonging to the same population pool
} 


\begin{tabular}{|c|c|c|c|c|c|c|c|c|c|c|c|c|}
\hline \multicolumn{10}{|c|}{ Table 3. Internal Consistency and Discriminant Validity } \\
\hline & $\boldsymbol{C R}$ & $\boldsymbol{\alpha}$ & $\boldsymbol{A V E}$ & $\boldsymbol{P I}$ & $\boldsymbol{W A}$ & $\boldsymbol{P A}$ & $\boldsymbol{S} \boldsymbol{C} \boldsymbol{S}$ & $\boldsymbol{S} \boldsymbol{Q}$ & $\boldsymbol{E} N$ & $\boldsymbol{D I}$ & $\boldsymbol{J U}$ & $\boldsymbol{T} \boldsymbol{R}$ \\
\hline PI & $\mathbf{0 . 9 4 9}$ & $\mathbf{0 . 9 2 0}$ & $\mathbf{0 . 8 6 1}$ & $\mathbf{0 . 9 2 8}$ & & & & & & & & \\
\hline WA & $\mathbf{0 . 9 5 9}$ & $\mathbf{0 . 9 4 4}$ & $\mathbf{0 . 8 5 5}$ & 0.675 & $\mathbf{0 . 9 6 3}$ & & & & & & & \\
\hline PA & $\mathbf{0 . 9 6 3}$ & $\mathbf{0 . 9 4 8}$ & $\mathbf{0 . 8 6 5}$ & 0.557 & 0.772 & $\mathbf{0 . 9 3 0}$ & & & & & & \\
\hline SCQ & $\mathbf{0 . 9 6 3}$ & $\mathbf{0 . 9 4 2}$ & $\mathbf{0 . 8 9 6}$ & 0.422 & 0.494 & 0.461 & $\mathbf{0 . 9 4 7}$ & & & & & \\
\hline SDQ & $\mathbf{0 . 9 7 2}$ & $\mathbf{0 . 9 5 7}$ & $\mathbf{0 . 9 2 1}$ & 0.422 & 0.560 & 0.599 & 0.315 & $\mathbf{0 . 9 6 0}$ & & & & \\
\hline EN & $\mathbf{0 . 9 3 6}$ & $\mathbf{0 . 9 0 9}$ & $\mathbf{0 . 7 8 8}$ & 0.520 & 0.710 & 0.667 & 0.544 & 0.608 & $\mathbf{0 . 8 8 7}$ & & & \\
\hline DI & $\mathbf{0 . 9 5 8}$ & $\mathbf{0 . 9 3 3}$ & $\mathbf{0 . 8 8 3}$ & 0.365 & 0.426 & 0.462 & 0.391 & 0.439 & 0.477 & $\mathbf{0 . 9 4 0}$ & & \\
\hline JU & $\mathbf{0 . 9 5 9}$ & $\mathbf{0 . 9 3 6}$ & $\mathbf{0 . 8 8 6}$ & 0.446 & 0.457 & 0.435 & 0.428 & 0.492 & 0.569 & 0.424 & $\mathbf{0 . 9 4 1}$ & \\
\hline TR & $\mathbf{0 . 9 6 2}$ & $\mathbf{0 . 9 5 1}$ & $\mathbf{0 . 8 3 6}$ & 0.574 & 0.669 & 0.641 & 0.499 & 0.704 & 0.193 & 0.400 & 0.184 & $\mathbf{0 . 9 1 4}$ \\
\hline
\end{tabular}

Note 1: $\mathrm{CR}=$ Composite Reliability; $\alpha=$ Cronbach's alpha; AVE = Average Variance Extracted Note 2: Diagonal shows the square root of AVE values.

Note 3: PI = Purchase Intention; WA = Website Appeal; PA = Product Appeal; SCQ = Service Content Quality; $\mathrm{SDQ}=$ Service Delivery Quality; EN = Enjoyment; DI = Diagnosticity; JU = Justifiability; TR = Trust.

\begin{tabular}{|c|c|c|c|c|}
\hline \multicolumn{5}{|l|}{ Table 4. Pseudo- $F$ Tests } \\
\hline Comparison & $\mathbf{R}^{2}$ excluded & $\mathbf{R}^{2}$ full & pseudo-F Statistic & df \\
\hline \multicolumn{5}{|c|}{ Excluding the Effect of Product Appeal on Website Appeal } \\
\hline Effect of Product Appeal on Website Appeal & 0.545 & 0.669 & $87.29 * * *$ & $(1,237)$ \\
\hline \multicolumn{5}{|c|}{ Excluding the Effect of Product Appeal and Website Appeal (Separately) on Purchase Intention } \\
\hline Effect of Website Appeal on Purchase Intention & 0.304 & 0.448 & $60.78 * * *$ & $(5,237)$ \\
\hline Effect of Product Appeal on Purchase Intention & 0.445 & 0.448 & 1.27 n.s. & $(5,237)$ \\
\hline
\end{tabular}

